\title{
Microfiltration Membranes Modified with Composition of Titanium Oxide and Silver Oxide by Magnetron Sputtering
}

\author{
Joanna Kacprzyńska-Gołacka ${ }^{1, * \mathbb{D}}$, Monika Łożyńska ${ }^{1}$, Wioletta Barszcz ${ }^{1}$, Sylwia Sowa ${ }^{1} \mathbb{D}$, Piotr Wieciński ${ }^{2}$ and \\ Ewa Woskowicz ${ }^{1}$
}

check for updates

Citation: Kacprzyńska-Gołacka, J.; Łożyńska, M.; Barszcz, W.; Sowa, S.; Wieciński, P.; Woskowicz, E.

Microfiltration Membranes Modified with Composition of Titanium Oxide and Silver Oxide by Magnetron Sputtering. Polymers 2021, 13, 141 https://doi.org/10.3390/polym 13010141

Received: 4 December 2020 Accepted: 28 December 2020 Published: 31 December 2020

Publisher's Note: MDPI stays neutral with regard to jurisdictional clai$\mathrm{ms}$ in published maps and institutional affiliations.

Copyright: (C) 2020 by the authors. Licensee MDPI, Basel, Switzerland. This article is an open access article distributed under the terms and conditions of the Creative Commons Attribution (CC BY) license (https:// creativecommons.org/licenses/by/ $4.0 /)$.
1 Łukasiewicz Research Networks-Institute for Sustainable Technology, 6/10 Pułaskiego St., 26-600 Radom, Poland; monika.lozynska@itee.lukasiewicz.gov.pl (M.Ł.); wioletta.barszcz@itee.lukasiewicz.gov.pl (W.B.); sylwia.sowa@itee.lukasiewicz.gov.pl (S.S.); ewa.woskowicz@itee.lukasiewicz.gov.pl (E.W.)

2 Faculty of Materials Science and Engineering, Warsaw University of Technology, 141 Woloska St., 02-507 Warsaw, Poland; piotr.wiecinski@gmail.com

* Correspondence: joanna.kacprzynska-golacka@itee.lukasiewicz.gov.pl; Tel./Fax: +48-48-364-93-32

\begin{abstract}
In this work, the authors present the possibility of modification of polymer membranes by $\mathrm{TiO}_{2}+\mathrm{AgO}$ coating created by the magnetron sputtering method. The two-component $\mathrm{TiO}_{2}+\mathrm{AgO}$ coating can improve and shape new functional properties such as bactericidal and photocatalytic properties. The influence of magnetron power changes on the structure of the membrane was investigated as well. The structure and elemental composition of $\mathrm{TiO}_{2}+\mathrm{AgO}$ coatings were analyzed using SEM and EDS technique. All deposited coatings caused a total inhibition of the growth of two investigated colonies of Escherichia coli and Bacillus subtilis on the surface. The photocatalytic properties for membranes covered with oxide coatings were tested under UV irradiation and visible light. The filtration result show that polymer membranes covered with two-component $\mathrm{TiO}_{2}+\mathrm{AgO}$ coatings have a permeate flux similar to the non-coated membranes.
\end{abstract}

Keywords: polyamide membranes; surface modification; magnetron sputtering; $\mathrm{TiO}_{2}+\mathrm{AgO}$ coatings; low-pressure plasma; plasma treatment

\section{Introduction}

Microfiltration (MF) processes conducted with polymer membranes play an increasingly important role in many areas of the industry [1,2]. Due to their advantages, such as simplicity and application flexibility, these techniques are used in a variety of technological processes. However, membrane filtration processes also have disadvantages. The specificity of this process creates good conditions for the formation and deposition of biofilm on the active surfaces of membranes (biofouling). This requires membranes to be cleaned or replaced more frequently leading to a reduction in filtration efficiency and an increase in filtration costs [3-5]. Membranes made from polymers in many cases can be easily exposed to biofouling [6]. Microbial biofilm can form in both cases: living or non-living surfaces and are prevalent in natural, industrial and hospital settings [7]. The deposition of components from the feed solution and the growth of bacteria on the surface and inside the pores of the membrane causes malfunctions of devices or the increase in material and energy consumption $[8,9]$.

Previous results evidenced an efficient modification of polymeric membrane surface by magnetron sputtering of metal oxide coatings that have the potential to prevent biofilm growth on the surface of the membranes $[10,11]$. This technology enables the production of thin coatings on the surface of the membrane providing various functional properties, which can improve the efficiency of membrane filtration and reduce the operating costs. The most extensively studied new material solutions (including membranes) concern hydrophilic and self-cleaning properties, which are based on metal oxides e.g., $\mathrm{TiO}_{2}$ [12-14]. 
These coating are non-toxic and characterized by high thermal and chemical stability and resistance to unfavorable environmental factors. Photocatalytic properties also determine the wide area of application for $\mathrm{TiO}_{2}$ as a self-cleaning coatings enabling the degradation of organic and inorganic compounds. In addition, these types of coating are characterized by a low water contact angle [15]. Nevertheless, the $\mathrm{TiO}_{2}$ coating itself shows bactericidal activity only in the presence of UV radiation $[16,17]$. The state of the art shows that doping the $\mathrm{TiO}_{2}$ coating with various metals, such as $\mathrm{Cu}, \mathrm{Zn}, \mathrm{Cr}$ or $\mathrm{Ag}$, can contribute to the improvement of its functional properties [18-21]. As observed in our previous work, the best solution is to dope titanium oxide $\left(\mathrm{TiO}_{2}\right)$ with silver oxide $(\mathrm{AgO})$, mainly due to the strong bactericidal activity of this material. The work carried out by the authors showed, that by using $\mathrm{AgO}$ coating for the modification of polymer membranes resulted in a $100 \%$ reduction of bacteria on its surface [11]. Moreover, it has been proved that the Ag doping expands the light absorption of $\mathrm{TiO}_{2}$ in the visible light region [22-24]. It should contribute to the improvement of the efficiency of the degradation of organic and inorganic compounds on the membrane surface.

The study investigated how changes in the technological parameters of the $\mathrm{TiO}_{2}+$ $\mathrm{AgO}$ coating deposition process influence the antibacterial effect as well as the structure and filtration efficiency of membranes. The application of magnetron sputtering technology is an innovative method, which generates functional thin films on the surface of the membrane. Herein, the authors have shown the possibility of using the magnetron sputtering technique to deposit of $\mathrm{TiO}_{2}+\mathrm{AgO}$ coatings on the surface of polymer microfiltration membranes in order to obtain antibacterial and photocatalytic properties. The influence of magnetron power changes on the structure of the membrane was also investigated. Structure and morphology of native and modified membranes were characterized. The bactericidal and photocatalytic properties of modified membranes, while retaining their filtration properties were confirmed as well.

\section{Materials and Methods}

\subsection{Coatings Deposition}

The $\mathrm{TiO}_{2}+\mathrm{AgO}$ coatings were deposited by reactive magnetron co-sputtering technology (MS-PVD) using a Standard 3 device produced by Ł-ITeE (Radom, Poland). The device was equipped with a two magnetron plasma sources located on the same wall in the chamber. Titanium and silver targets were used at the same time of the deposition process. The purity of both targets was $99.99 \%$. The targets diameter was about $100 \mathrm{~mm}$ and the distance between the sample and the targets was $200 \mathrm{~mm}$. The coatings were deposited with a reactive gas atmosphere composed of a mixture of 10\% oxygen (99.9999\% purity) and $90 \%$ argon (99.9999\% purity). The $\mathrm{TiO}_{2}+\mathrm{AgO}$ coatings were prepared without the negative potential substrate polarization. The power of Ti magnetron source was variable in the range $650-1000 \mathrm{~W}$. The power of Ag magnetron source was variable in the range $2580 \mathrm{~W}$. The time of the MS-PVD process was $30 \mathrm{~s}$.

\subsection{Structure and Elemental Composition Characterization}

The Hitachi Su-8000 scanning electron microscope (SEM; Tokyo, Japan) equipped with an electron gun with cold field emission was using for structure characterization of prepared coatings. The very good resolution with a relatively low beam current in this type of electron source is beneficial for observing materials sensitive to the electron beam, such as the analyzed membranes. The secondary electron signal (SE) was used for material observation but there was not deposited a conductive layer on the sample. The elemental composition of the tested material was determined by the EDX method.

\subsection{Bactericidal Properties}

Antibacterial properties of membranes modified with $\mathrm{TiO}_{2}+\mathrm{AgO}$ were examined for microorganisms that were representative of Gram-negative (Escherichia coli) and Grampositive (Bacillus subtilis) bacteria. Before microbiological tests, the membranes were 
sterilized with a UV-C lamp for $\mathrm{t}=30 \mathrm{~min}$. Microbiological tests were carried out using a vacuum filtration kit. An inoculum of the used bacteria was prepared in a saline buffer $\left(\mathrm{KH}_{2} \mathrm{PO}_{4}\right.$, Chempur) from a 24-hour culture at a concentration of $1.5-3.0 * 10^{5} \mathrm{CFU} / \mathrm{cm}^{3}$. The obtained suspension was further diluted using the serial dilution method to achieve a countable number of colonies on the membranes. From the prepared dilutions, $0.04 \mathrm{~cm}^{3}$ (for Escherichia coli) and $0.1 \mathrm{~cm}^{3}$ (for Bacillus subtilis) of the suspension were taken and transferred to a sterile $1000 \mathrm{~cm}^{3}$ phosphate buffer. Then $10 \mathrm{~cm}^{3}$ of such prepared suspension, which was prepared in this way was filtered through the membranes under a pressure of 500 mbar using vacuum filtration kit. The membranes were placed on the plates containing Luria Bertani (LB, VWR) growth medium and incubated at $37^{\circ} \mathrm{C}$ for $24 \mathrm{~h}$. After this time, the bacterial colonies that had grown on the membranes were counted. The reference sample in the research was the unmodified membrane. Results of antibacterial activity of the membranes were expressed as the percentage $(\%)$ reduction in the colony (CFU) counts.

\subsection{Photocatalytic Properties}

Photocatalytic properties of the membranes were evaluated on the degree of methylene blue degradation $(0.1 \% v / v$, Science Company) under the UV and visible light. Polyamide membranes unmodified and modified with two-component $\mathrm{TiO}_{2}+\mathrm{AgO}$ coatings were placed in Petri dishes. A $20 \mathrm{~cm}^{3}$ volume was applied to their surface. Both UV-A lamp and daylight were used to study the effect of the type of UV radiation on the photocatalytic properties. After 8, 24, 48 and $72 \mathrm{~h}$ of $\mathrm{UV}$ and visible light irradiation, spectrophotometric measurements were made at $665 \mathrm{~nm}$ using a Hach DR 6000 spectrophotometer (Hach Company, Loveland, CO, USA). The tests were repeated three times for each tested sample. In order to investigate the effect of doping $\mathrm{TiO}_{2}$ coatings with $\mathrm{AgO}$ on the photocatalytic properties in visible light, one-component coatings were also tested according to the same methodology.

\subsection{Filtration Properties}

The permeate flux was determined by measuring the time required to filter deionized water $\left(100 \mathrm{~cm}^{3}\right)$ through the membrane $\left(8 \mathrm{~cm}^{2}\right)$ under defined transmembrane pressure (500 mbar). The deionized water was characterized by the conductivity and $\mathrm{pH}$ of $5.3 \mu \mathrm{S} / \mathrm{cm}$ and 6.5, respectively. For this purpose, the laboratory "dead-end" filtration set-up was used. The filtration properties of the membranes were evaluated based on the permeate flux (Equation (1)).

A "dead-end" vacuum system, operating at a pressure of 0.5 bar, was used to determine the permeate flux. The permeate flux $\left(J_{p}\right)$ was calculated from the time $(t)$ taken to filter $100 \mathrm{~cm}^{3}\left(V_{p}\right)$ of deionized water through a membrane with an area of $8 \mathrm{~cm}^{2}(A)$ in accordance with Equation (1).

$$
J_{P}=\frac{V_{p}}{A \cdot t}
$$

\section{Results and Discussion}

\subsection{Structure and Elemental Composition Characterization}

The SEM images of the membranes coated with $\mathrm{TiO}_{2}+\mathrm{AgO}$ were prepared for a different power of the magnetron source $\left(\mathrm{P}_{\mathrm{M}-\mathrm{Ag}}=25 \mathrm{~W}, 50 \mathrm{~W}\right.$ and $80 \mathrm{~W}, \mathrm{P}_{\mathrm{M}-\mathrm{Ti}}=650 \mathrm{~W}$ and $1000 \mathrm{~W}$ ) used for modification were shown in Figures 1 and 2. The SEM analysis of the structure of membrane with $\mathrm{TiO}_{2}+\mathrm{AgO}$ coatings showed the comparison of the differences to non-coated membrane presented in Figure 3. 

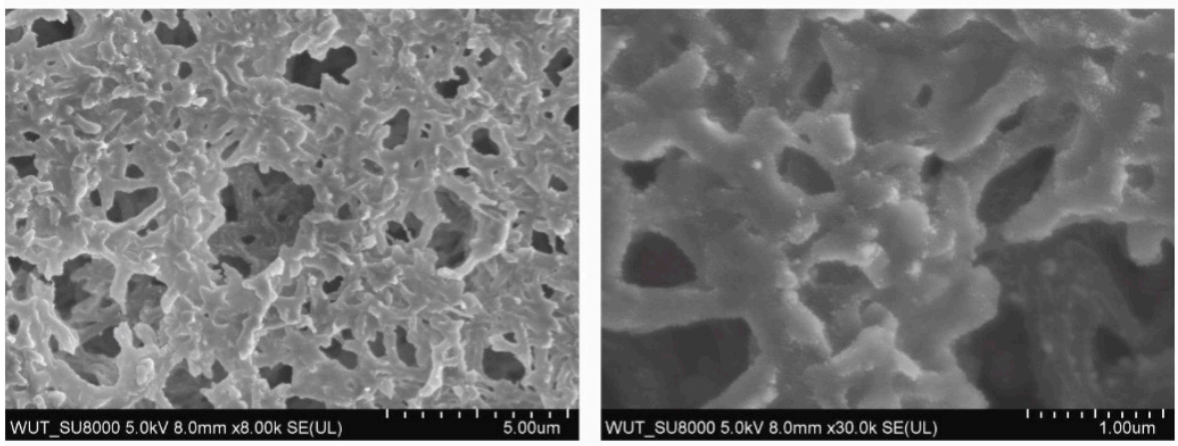

a)
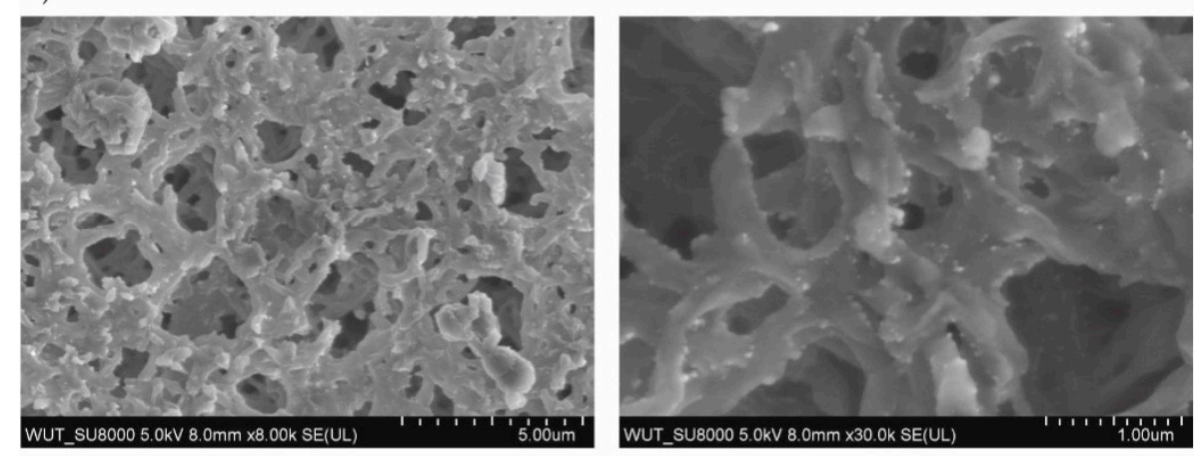

b)
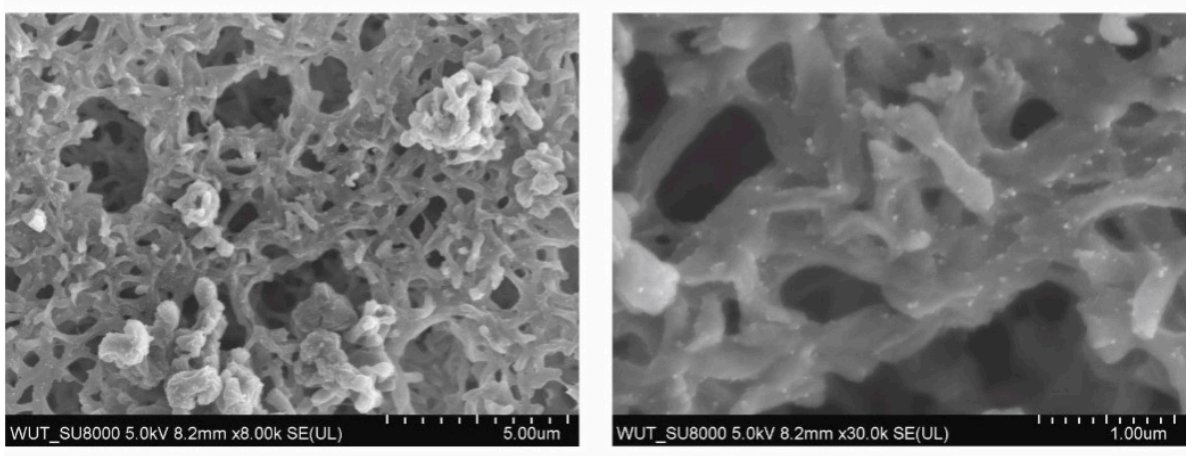

c)

Figure 1. SEM images of the membranes with $\mathrm{TiO}_{2}+\mathrm{AgO}$ coatings deposited at the different magnetron powers $\mathrm{P}_{\mathrm{M}}(\mathbf{a}) \mathrm{P}_{\mathrm{M}-\mathrm{Ag}}=80 \mathrm{~W}, \mathrm{P}_{\mathrm{M}-\mathrm{Ti}}=1000 \mathrm{~W}, \mathrm{t}=30 \mathrm{~s},(\mathbf{b}) \mathrm{P}_{\mathrm{M}-\mathrm{Ag}}=50 \mathrm{~W}, \mathrm{P}_{\mathrm{M}-\mathrm{Ti}}=1000 \mathrm{~W}$, $\mathrm{t}=30 \mathrm{~s},(\mathrm{c}) \mathrm{P}_{\mathrm{MAg}}=25 \mathrm{~W}, \mathrm{P}_{\mathrm{M}-\mathrm{Ti}}=1000 \mathrm{~W}, \mathrm{t}=30 \mathrm{~s}$.

The SEM analysis showed that the structure of the membrane's surface changed depending on the magnetron power. In the case of coatings created with the magnetron power $\mathrm{P}_{\mathrm{MTi}}=1000 \mathrm{~W}$ (Figure 1), the multiple bright AgO particles smaller than $100 \mathrm{~nm}$ were observed in their structure. The proportion of these particles decreased as the power $\mathrm{P}_{\mathrm{M}-\mathrm{Ag}}$ of the magnetron decreased. In the case of coatings created with smaller magnetron power $\mathrm{P}_{\mathrm{M}-\mathrm{Ti}}=650 \mathrm{~W}$ (Figure 2), much fewer light particles were observed on the surface. The particles were localized mainly inside the pores, as presented in Figure 3. The correlation between the magnetron power and the number of $\mathrm{AgO}$ particles on the membrane surface has remained unclear.

The elemental composition analysis included the assessment of the magnetron power effect on the percentage content for individual metallic elements in the elemental composition of the coating. The obtained results showed, that the $\mathrm{TiO}_{2}+\mathrm{AgO}$ coatings (Figure 4) created at the higher magnetron power $\mathrm{P}_{\mathrm{MTi}}=1000 \mathrm{~W}$ were characterized by a higher content of Ti compared to the coatings deposited at the power of $\mathrm{P}_{\mathrm{M}-\mathrm{Ti}}=650 \mathrm{~W}$. The increase of the magnetron power $\mathrm{P}_{\mathrm{M}-\mathrm{Ag}}$ resulted in the increase of $\mathrm{Ag}$ content in the elemental composition of the tested coatings. 

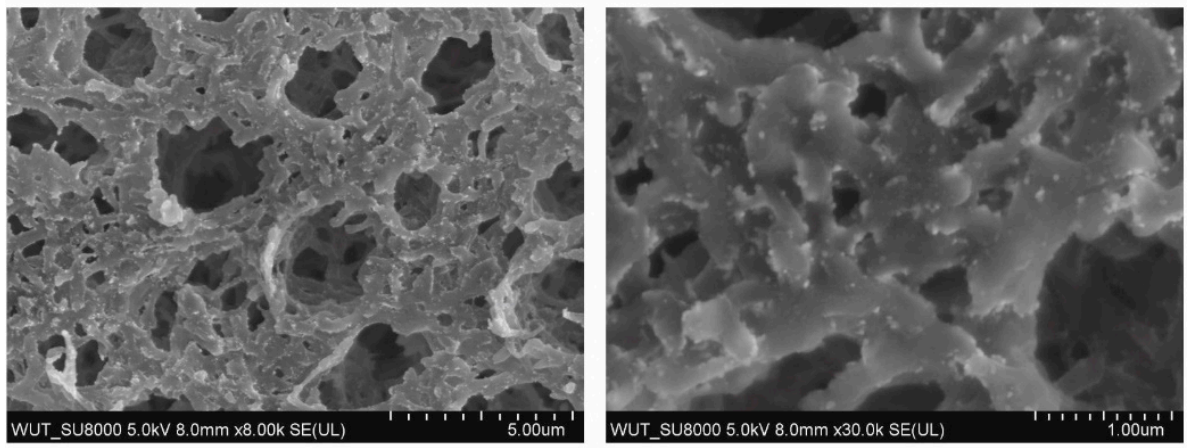

a)
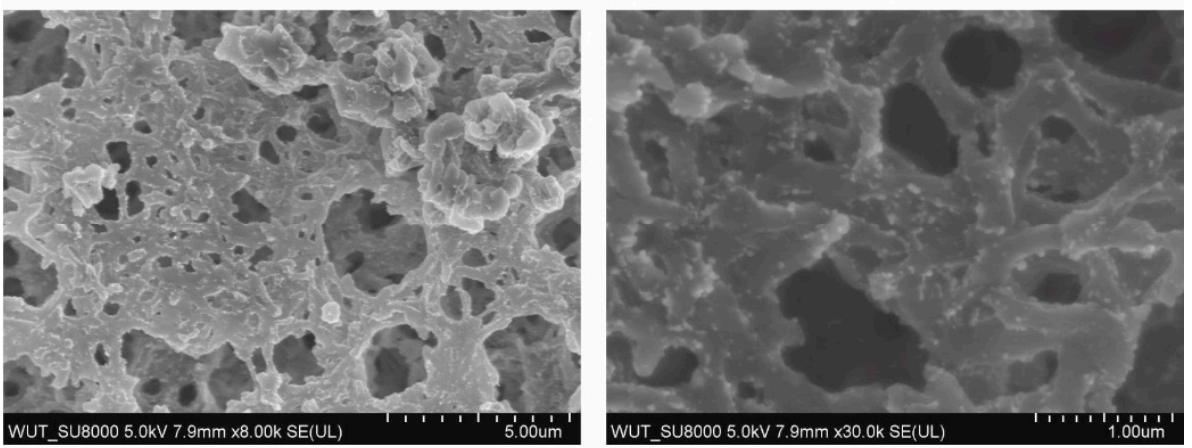

b)
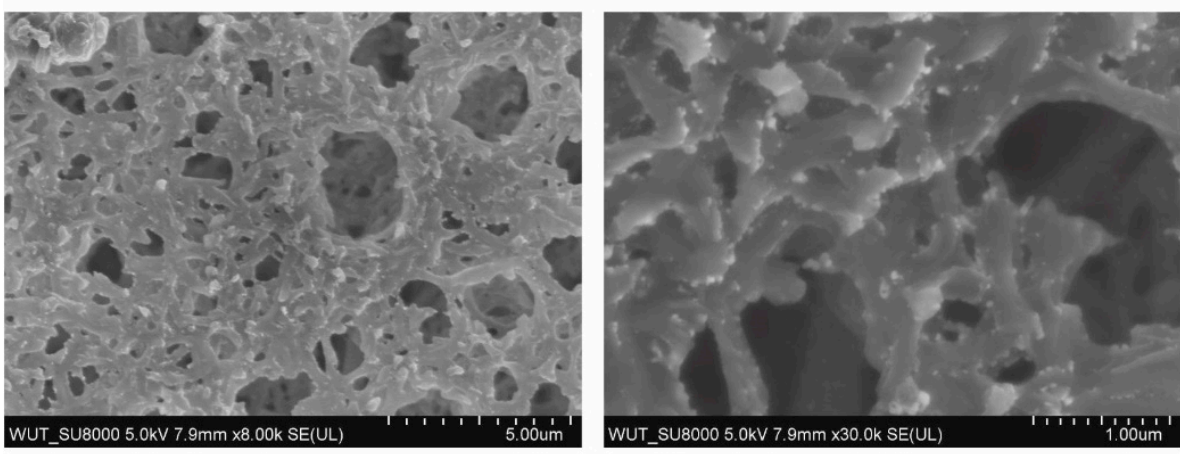

c)

Figure 2. SEM images of the membranes with $\mathrm{TiO}_{2}+\mathrm{AgO}$ coatings deposited at the different magnetron powers $\mathrm{P}_{\mathrm{M}}(\mathbf{a}) \mathrm{P}_{\mathrm{M}-\mathrm{Ag}}=80 \mathrm{~W}, \mathrm{P}_{\mathrm{M}-\mathrm{Ti}}=650 \mathrm{~W}, \mathrm{t}=30 \mathrm{~s},(\mathbf{b}) \mathrm{P}_{\mathrm{M}-\mathrm{Ag}}=50 \mathrm{~W}, \mathrm{P}_{\mathrm{M}-\mathrm{Ti}}=650 \mathrm{~W}$, $\mathrm{t}=30 \mathrm{~s},(\mathrm{c}) \mathrm{P}_{\mathrm{MAg}}=25 \mathrm{~W}, \mathrm{P}_{\mathrm{M}-\mathrm{Ti}}=650 \mathrm{~W}, \mathrm{t}=30 \mathrm{~s}$

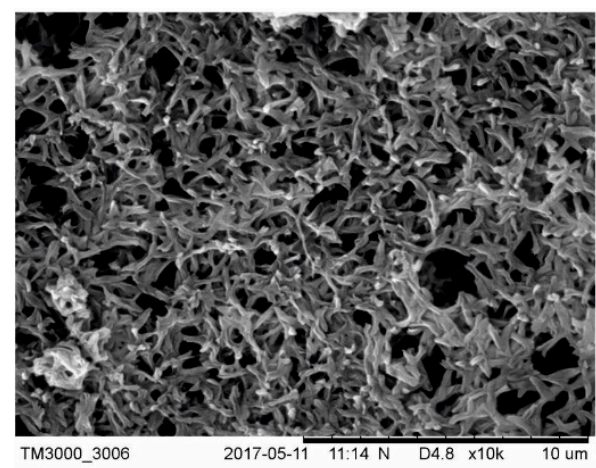

a)

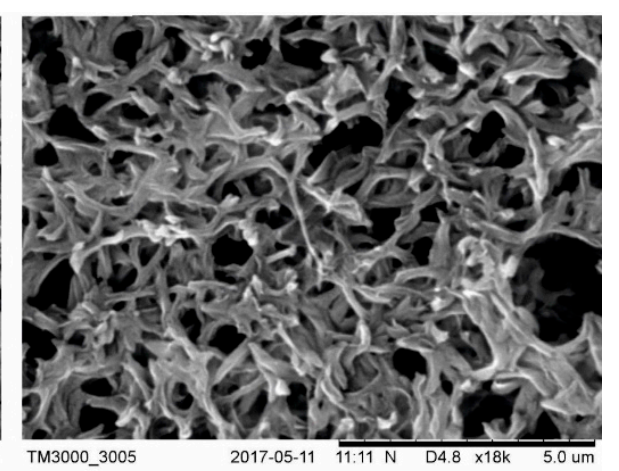

b)

Figure 3. SEM images of the non-coated membranes: (a) magnification $10,000 \times,(\mathbf{b})$ magnification $18,000 \times$. 


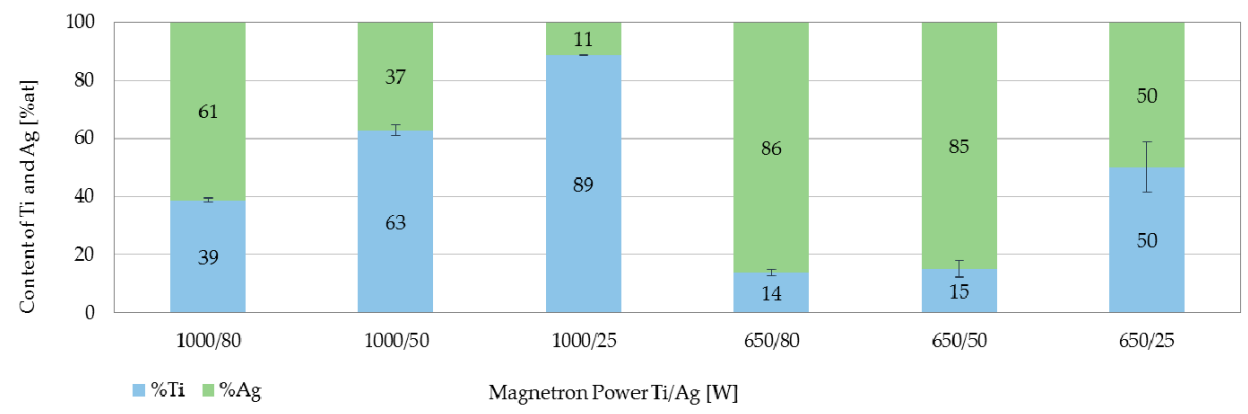

Figure 4. Elemental composition of $\mathrm{TiO}_{2}+\mathrm{AgO}$ coatings deposited at different magnetron powers.

\subsection{Antibacterial Properties}

The antibacterial activity of membranes modified by $\mathrm{TiO}_{2}+\mathrm{AgO}$ coatings was specified against two representative bacteria such as Escherichia coli (E.coli) and Bacillus subtilis (B.subtilis), respectively. The coatings generated with the following power of magnetron source $\left(\mathrm{P}_{\mathrm{M}-\mathrm{Ag}}=25 \mathrm{~W}, 50 \mathrm{~W}\right.$ and $80 \mathrm{~W}, \mathrm{P}_{\mathrm{MTi}}=650 \mathrm{~W}$ and $\left.1000 \mathrm{~W}\right)$ lead to the complete growth inhibition of the colonies of E.coli and B.subtilis on the membranes which is shown in Figure 5. Both bacteria showed no growth on the agar plates after incubation.
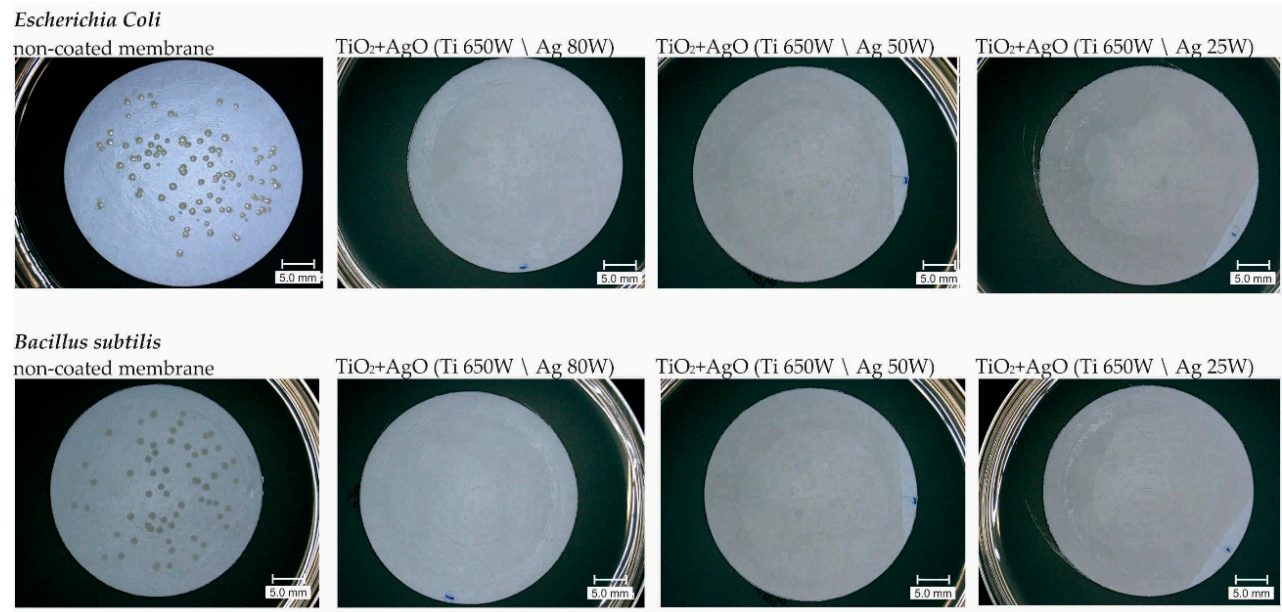

a)

Escherichia Coli
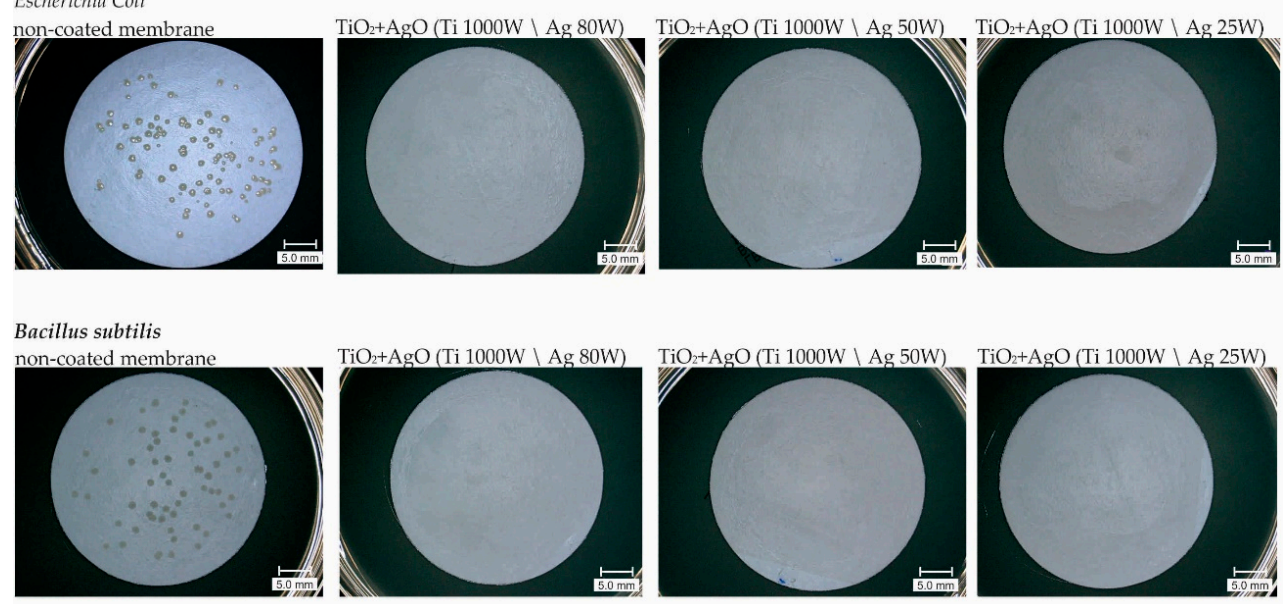

b)

Figure 5. 3D microscope images of $\mathrm{TiO}_{2}+\mathrm{AgO}$ coated membranes after filtration of bacterial suspensions: $(\mathbf{a}) \mathrm{TiO}_{2}+\mathrm{AgO}$ modified membranes $\left(\mathrm{P}_{\mathrm{M}-\mathrm{Ag}}=25 \mathrm{~W}, 50 \mathrm{~W}\right.$ and $\left.80 \mathrm{~W} ; \mathrm{P}_{\mathrm{M}-\mathrm{Ti}}=650 \mathrm{~W}\right) ;(\mathbf{b}) \mathrm{TiO}_{2}+\mathrm{AgO}$ modified membranes $\left(\mathrm{P}_{\mathrm{M}-\mathrm{Ag}}=25 \mathrm{~W}\right.$, $50 \mathrm{~W}$ and $\left.80 \mathrm{~W} ; \mathrm{P}_{\mathrm{M}-\mathrm{Ti}}=1000 \mathrm{~W}\right)$. 
These results were similar to those obtained in the previous study, where the $\mathrm{AgO}$ coated membranes with different power of magnetron source caused total growth inhibition of E. coli and B. subtilis [11]. The results of reduction (\%) in CFU counts are presented in Figure 6. For each $\mathrm{TiO}_{2}+\mathrm{AgO}$ modified membranes the antibacterial activity of the membrane amounted to $100 \%$ compared to the no-coated membrane.

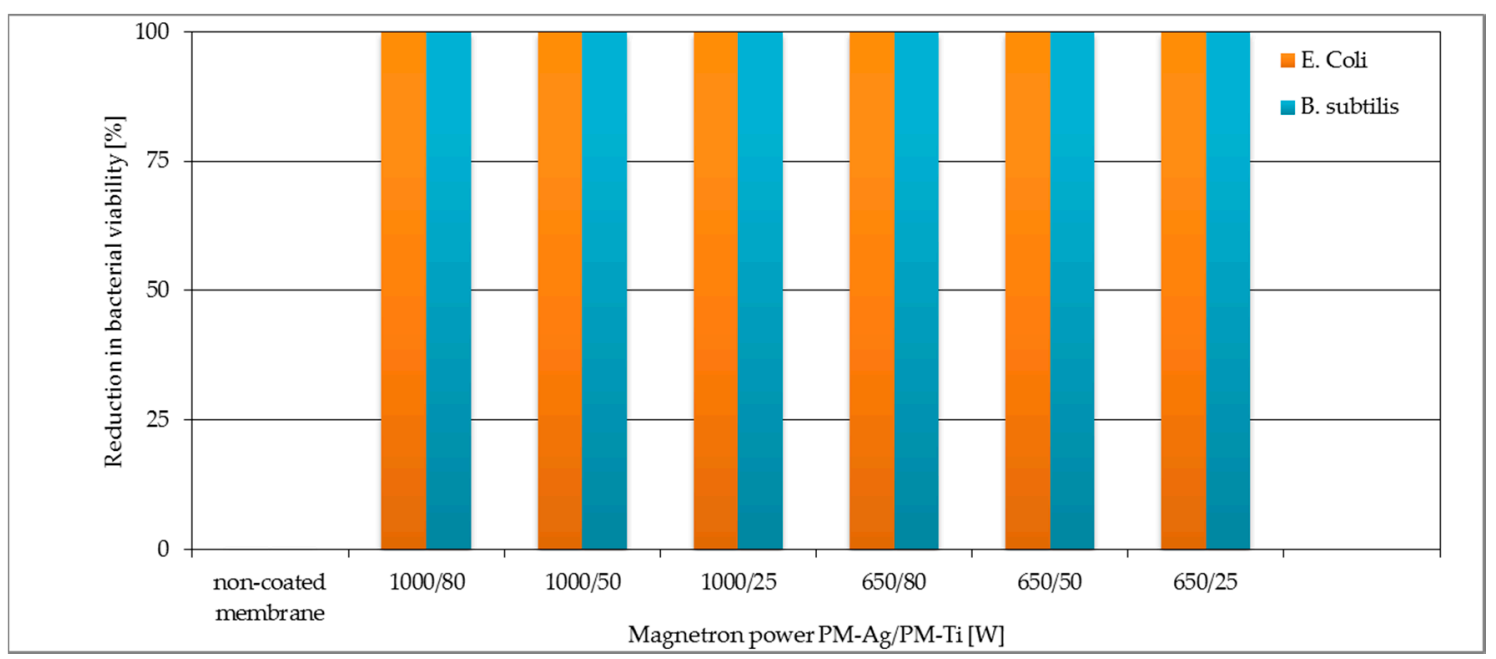

Figure 6. Reduction [\%] CFU counts of Escherichia coli and Bacillus subtilis on no-coated membrane and membranes covered with $\mathrm{TiO}_{2}+\mathrm{AgO}$ coating deposited during $30 \mathrm{~s}$ at different magnetron powers $\mathrm{P}_{\mathrm{M}-\mathrm{Ti}}$ and $\mathrm{P}_{\mathrm{M}-\mathrm{Ag}}$.

The obtained results may be associated with the elemental composition of the coatings, which created with MS-PVD technique. The deposited coatings on the polymer membrane were in the form of a solid titanium oxide matrix where $\mathrm{Ag} / \mathrm{AgO}$ nanoparticles were embedded, (Figures 2 and 3). The bactericidal properties of the $\mathrm{TiO}_{2}+\mathrm{AgO}$ composite coating were probably related to the presence of silver/silver oxide $(\mathrm{Ag} / \mathrm{AgO})$ nanoparticles in this coatings. Research by Thukkaram et al. confirmed that the enrichment of the titanium oxide coating with silver nanoparticles increases the antimicrobial activity against Gram-positive and Gram-negative bacteria [25]. Navabpour et al. proved that $\mathrm{TiO}_{2}+\mathrm{AgO}$ coatings formed by using the reactive magnetron sputtering have stronger bactericidal properties than $\mathrm{TiO}_{2}$ coatings produced in the same ways [26]. The strong bactericidal properties of silver/silver oxide ( $\mathrm{Ag} / \mathrm{AgO})$ nanoparticles were confirmed in many studies [27-29]. Silver and silver oxide nanoparticles have an affinity for functional groups included in cellular proteins and nucleic acids. The binding silver ions in the cytoplasmic membrane of the bacterial cell cause their accumulation and its destabilization and increase in membrane permeability. As a consequence, this leads to the uncontrolled transport of protons and depolarization of cell membrane, and death of microorganisms [30]. The antibacterial activity of silver and silver oxide nanoparticles can be associated with free radicals, which they generated. The free radicals cause oxidative stress in bacterial cells. $\mathrm{Li}$ et al. compared the relationship between the antimicrobial activity of nanoparticles of various metal oxides and oxidative stress. The viability of E.coli cells in solutions of metal oxide nanoparticles under the influence of UV radiation was reduced [31].

\subsection{Photocatalytic Properties}

The membranes with two-component coatings were subjected to photocatalytic tests. The results obtained for $\mathrm{TiO}_{2}+\mathrm{AgO}$ coatings after irradiation with a UV lamp and daylight are presented in Figures 7 and 8, respectively. 


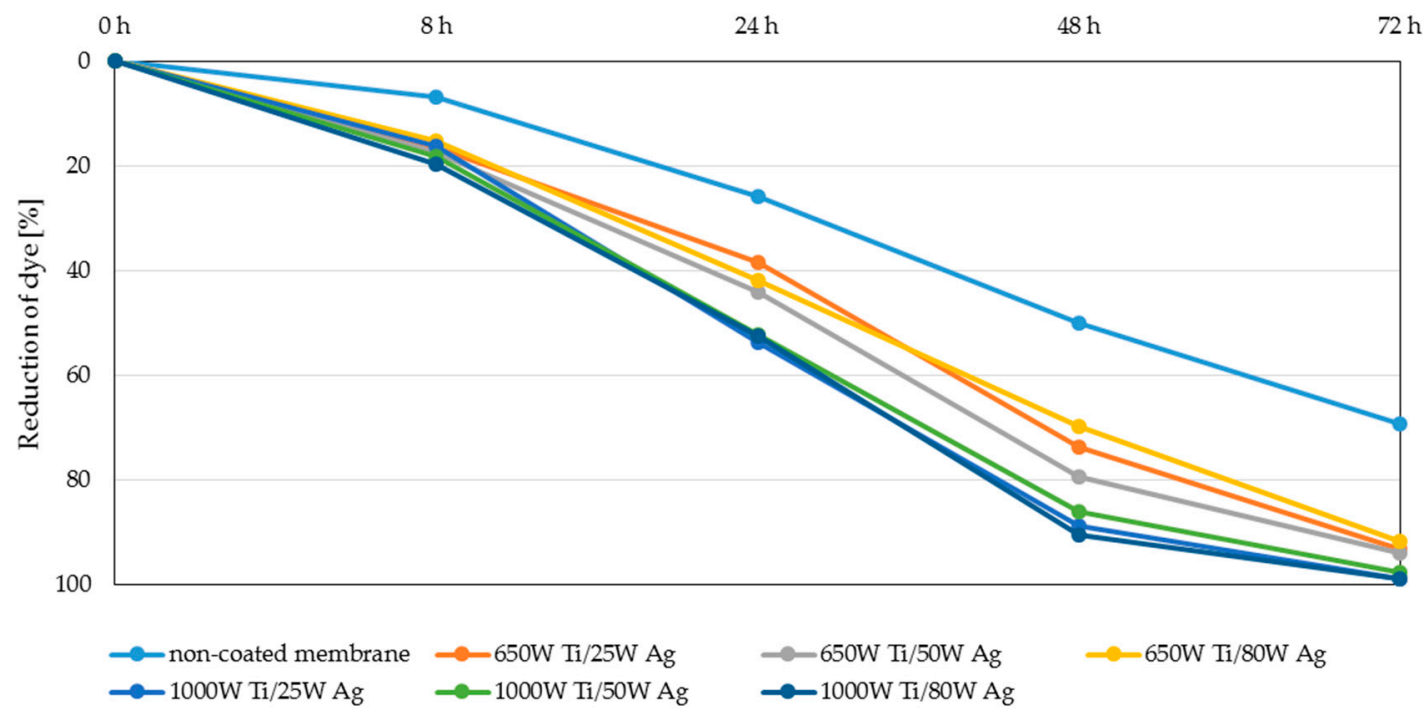

Figure 7. Reduction of the MB dye under the influence of UV-A light.

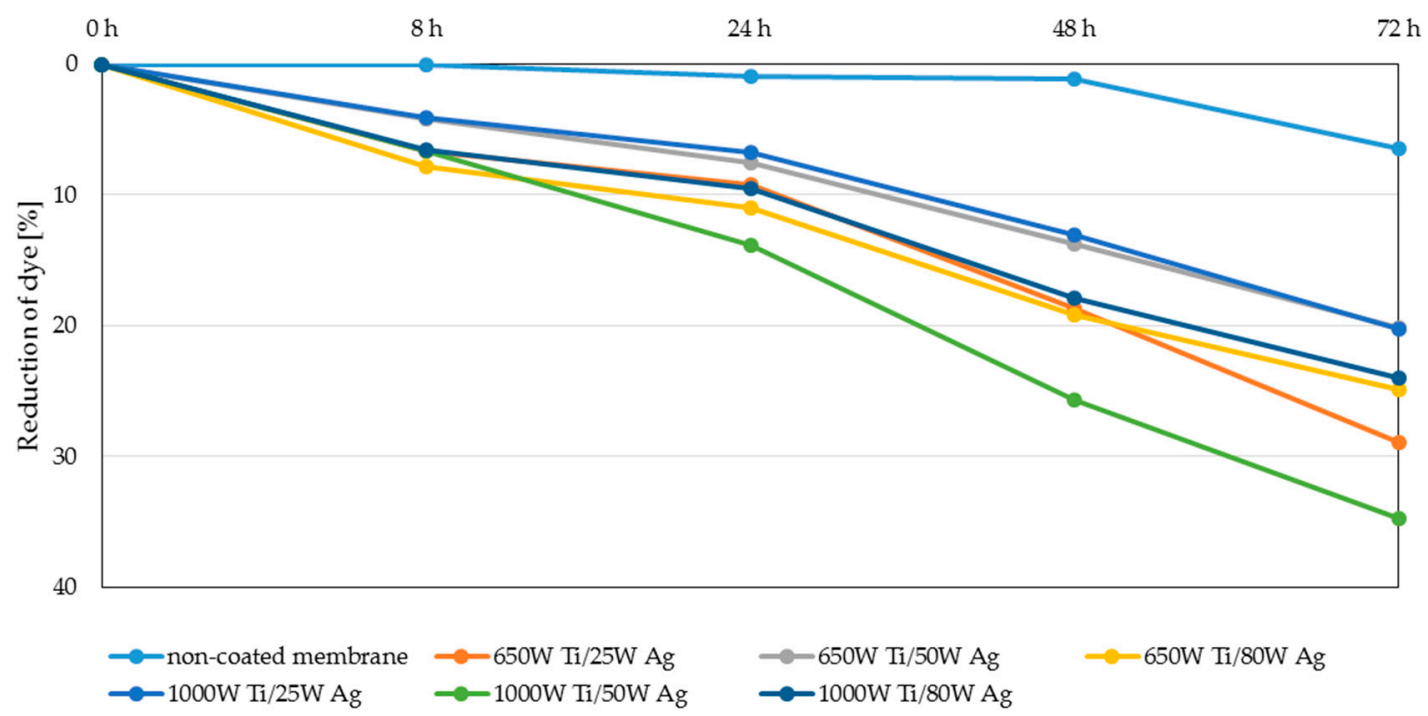

Figure 8. Reduction of the MB dye under the influence of visible light.

As shown in Figure 7 the membranes with $\mathrm{TiO}_{2}+\mathrm{AgO}$ coatings deposited with the magnetron power $\mathrm{P}_{\mathrm{M}-\mathrm{Ti}}=1000 \mathrm{~W}$ showed better photocatalytic properties after irradiation UV lamp than the coatings deposited with the magnetron power $\mathrm{P}_{\mathrm{M}-\mathrm{Ti}}=650 \mathrm{~W}$ (Figure 7). For all types of coatings with $\mathrm{P}_{\mathrm{M}-\mathrm{Ti}}=1000 \mathrm{~W}$ over $90 \%$ reduction of the dye was achieved after $72 \mathrm{~h}$. The literature and own research data show that titanium oxide is a substantial photocatalytic factor in UV light $[32,33]$. The doping of the coatings with silver oxide (AgO) for bactericidal and photocatalytic properties in visible light does not negatively influence photocatalytic properties under UV light.

The highest degree of dye reduction was achieved for membranes with magnetron power $1000 \mathrm{~W} \mathrm{Ti} / 50 \mathrm{~W}$ Ag and coatings with magnetron power $650 \mathrm{~W}$ Ti/25 W Ag (35 and $28 \%$ respectively) can be observed when two-component coatings are exposed to daylight. The achieved degree of dye reduction was much lower than that of UV irradiation. This is due to the fact that both $\mathrm{TiO}_{2}$ and $\mathrm{AgO}$ do not have photocatalytic properties in visible light. Normally, with light irradiation UV for titanium oxide, an electron from the valence band can be promoted to the conduction band, leaving an electron. This deficiency is known as a hole in the valence band and is causing an excess of negative charge in the conduction band. These generated species can participate in surface redox reactions and generate 
secondary reactive oxygen species. However, the excited reactive electron is unstable, and it can return to the valence band, to be stable again, provoking recombination. Studies revealed, that doping of silver improves the photocatalytic activity of $\mathrm{TiO}_{2}$ inducing an efficient surface plasmon resonance effect under sunlight. That prevents the recombination of $\mathrm{e}^{-}-\mathrm{h}^{+}$pairs, which is responsible for the decreasing process of the photocatalytic activity of $\mathrm{TiO}_{2}$ [34-38]. In order to assess the effect of doping titanium oxide coating with silver oxide, additional experiments were conducted in visible light for one-component coatings. The results are presented in Figure 9.

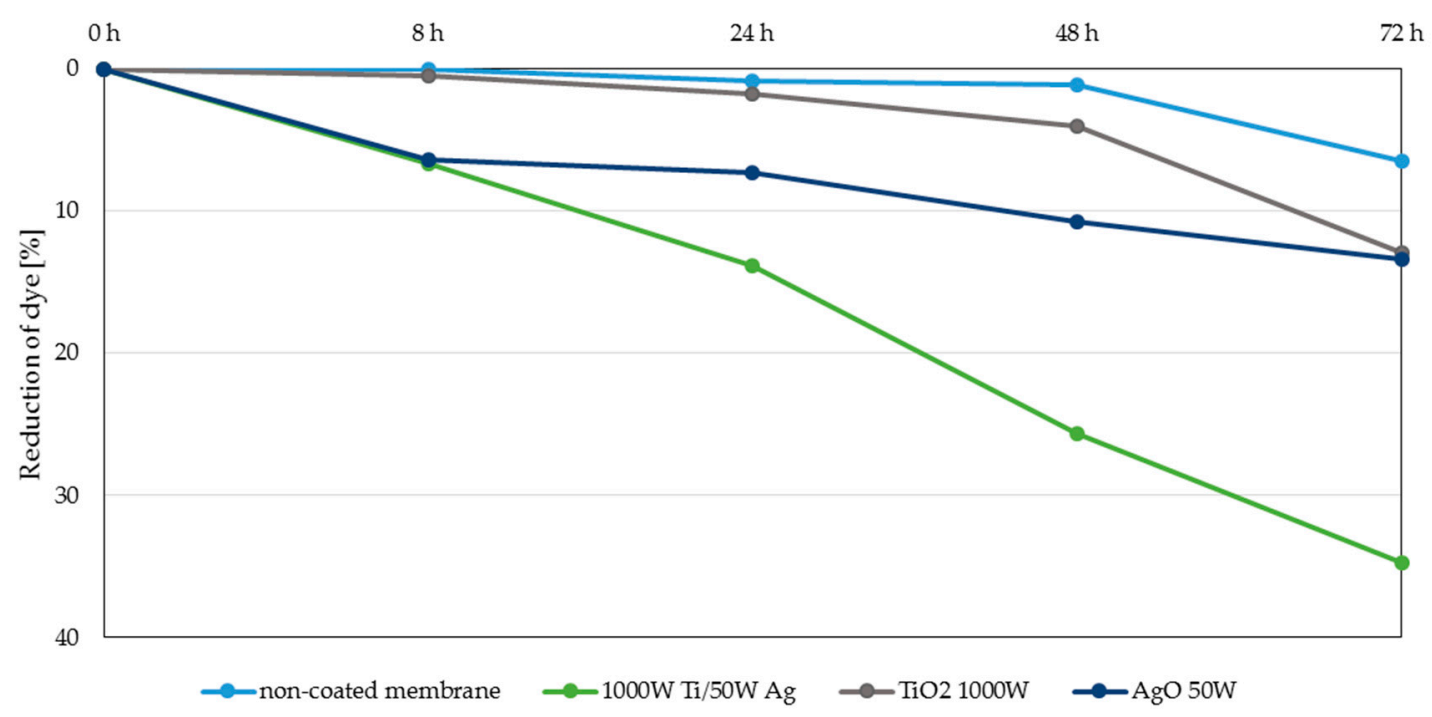

Figure 9. Reduction of the MB dye under the influence of visible light.

The obtained results showed that the tested one-component $\mathrm{TiO}_{2}$ coating and $\mathrm{AgO}$ coatings have lower photocatalytic activity and yielded an approx. $10 \%$ reduction of the dye after $72 \mathrm{~h}$. Doping the titanium oxide coating with silver oxide caused an even more than threefold increase in the photocatalytic properties of these membranes. The catalytic properties of such prepared membranes are influenced by many factors, including the quantity and size of the silver particles $[35,36]$, which was confirmed during this study. In the case of the tested two-component coatings, the highest dye reduction was obtained for coatings with a silver content between 50 and $60 \%$ (Figure 2). The decomposition of MB dye in visible light was not as intense for the coating with the highest $\mathrm{Ag}$ content $(90 \%$ for $1000 \mathrm{~W} \mathrm{Ti} / 80 \mathrm{~W}$ Ag coatings) or the lowest one (about 15\% for $650 \mathrm{~W} \mathrm{Ti} / 50 \mathrm{~W}$ Ag and $650 \mathrm{~W} \mathrm{Ti} / 80 \mathrm{~W}$ coatings).

\subsection{Filtration Properties and Stability of the Coatings}

The results of the filtration and transport properties analysis for polymer membranes coated with two-component $\mathrm{TiO}_{2}+\mathrm{AgO}$ coatings showed an inconsiderable decrease in the permeate flux compared to the native membrane (Figures 10 and 11). The highest $(27 \%)$ decrease in the permeate flux compared to the native membrane was recorded (Figure 10) in the case of the membrane with the coating deposited at the magnetron powers $\mathrm{P}_{\mathrm{M}-\mathrm{Ti}}=650 \mathrm{~W}$ and $\mathrm{P}_{\mathrm{M}-\mathrm{Ag}}=80 \mathrm{~W}$. Reducing the power of the $\mathrm{P}_{\mathrm{M}-\mathrm{Ag}}$ magnetron resulted in an improvement of the permeate flux. After increasing the magnetron power to $\mathrm{P}_{\mathrm{M}-\mathrm{Ti}}=1000 \mathrm{~W}$, a significant improvement in the filtration properties was observed. The permeate flux was comparable to the non-coated membrane (Figure 11) for the membrane with the coating deposited at the magnetron powers $\mathrm{P}_{\mathrm{M}-\mathrm{Ag}}=25 \mathrm{~W}$ and $\mathrm{P}_{\mathrm{MAg}}=50 \mathrm{~W}$. 


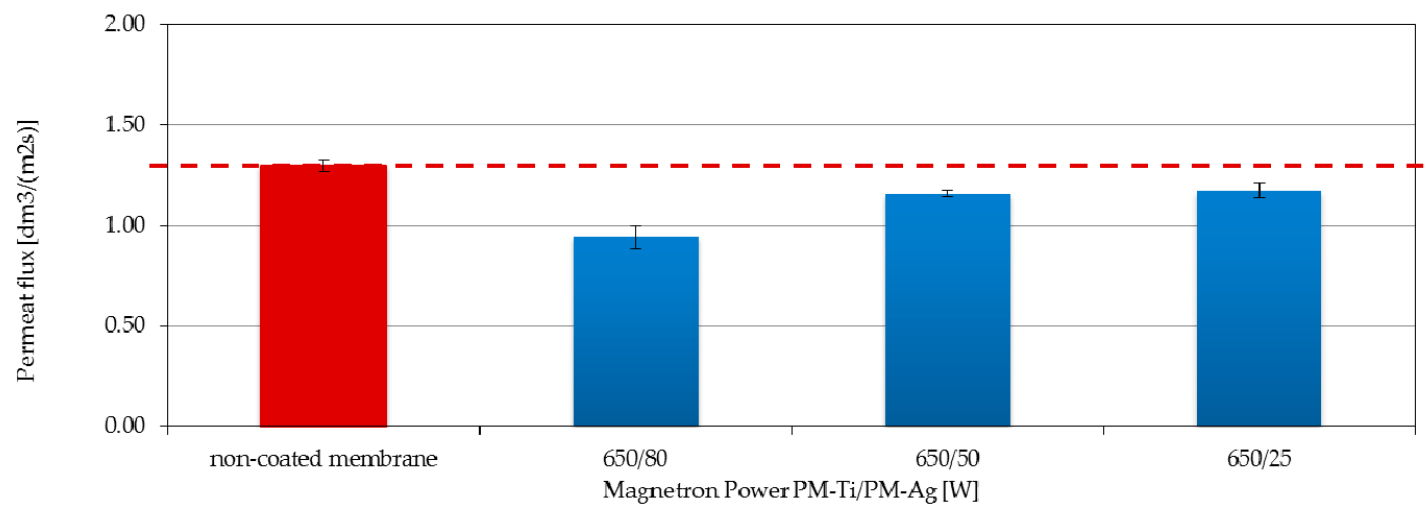

Figure 10. Effect of the $\mathrm{P}_{\mathrm{M}-\mathrm{Ag}}$ magnetron power on the permeate flux of membranes covered with $\mathrm{TiO}_{2}+\mathrm{AgO}_{\text {coatings }}$ deposited at a constant power $\mathrm{P}_{\mathrm{M}-\mathrm{Ti}}=650 \mathrm{~W}$.

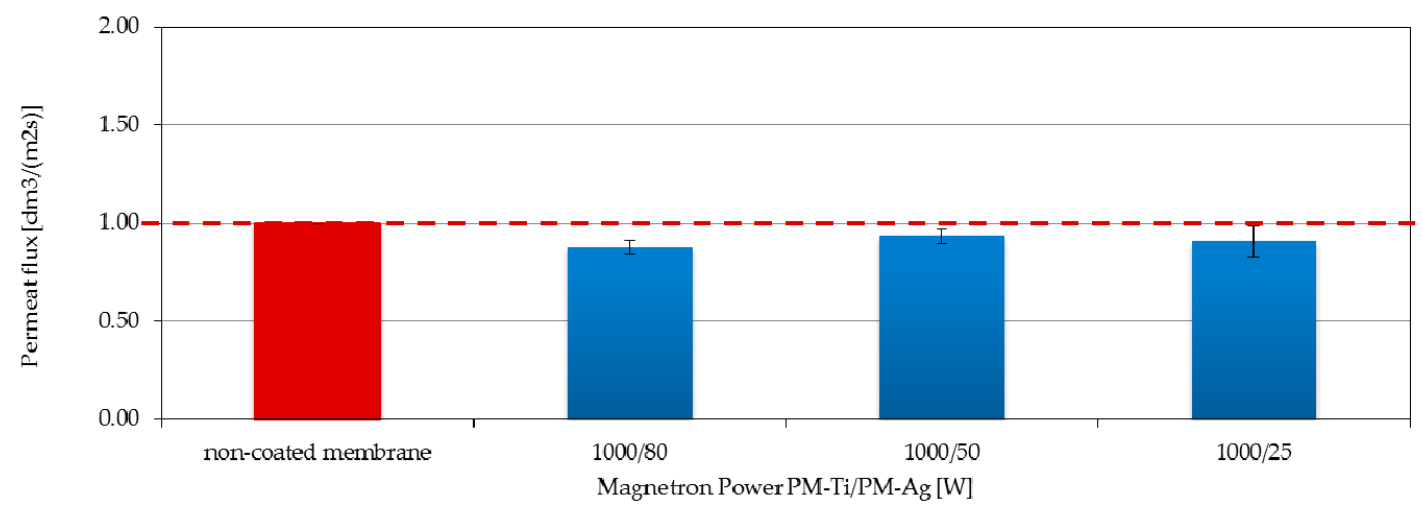

Figure 11. Effect of the $\mathrm{P}_{\mathrm{M}-\mathrm{Ag}}$ magnetron power on the permeate flux of membranes covered with $\mathrm{TiO}_{2}+\mathrm{AgO}_{\text {coatings }}$ deposited at a constant power $\mathrm{P}_{\mathrm{M}-\mathrm{Ti}}=1000 \mathrm{~W}$.

The increasing of the magnetron power $\mathrm{P}_{\mathrm{M} \text {-Ti }}$ caused the increase of the proportion of hydrophilic $\mathrm{TiO}_{2}[15]$ in the coating structure and it can improve the hydrophilic properties of the whole coating, and consequently also the membrane surface. As a consequence, the filtration performance of the membrane will be most likely improved. The opposite situation was observed when the power $\mathrm{P}_{\mathrm{M}-\mathrm{Ag}}$ was increased. It caused an increase in the proportion of hydrophobic $\mathrm{AgO}$ in the coating structure. This can lead to a reduction in the hydrophilic properties of the membrane surface, which results in a decrease in its filtration properties.

\section{Conclusions}

In this study, the importance of an interdisciplinary approach was highlighted towards novel trends in the development of materials based on polymer membranes. Using the MS-PVD method can provide new functional properties for polymeric membranes. In the article, the different magnetron powers of Ti and $\mathrm{Ag}$ were used to create two-component coatings with new, common properties. Based on the surface analysis of the membrane the presence of $\mathrm{AgO}$ nanoparticles were observed. The size of these particles was smaller than $100 \mathrm{~nm}$ for magnetron power $\mathrm{P}_{\mathrm{M}-\mathrm{Ti}}=1000 \mathrm{~W}$. Research has shown that the magnetron power has effects on the percentage content for individual metallic elemental composition. The presence of $\mathrm{AgO}$ nanoparticles was related to the island nature of the $\mathrm{AgO}$ coating grown on a polymer substrate [11]. The antibacterial properties of $\mathrm{TiO}_{2}+\mathrm{AgO}$ coatings were determined for the two following bacteria: Escherichia coli and Bacillus subtilis. $\mathrm{The}^{\mathrm{TiO}_{2}}$ $+\mathrm{AgO}$ coatings deposited at different magnetron powers resulted in complete reduction of growth of two representative bacteria. It was related to the presence of $\mathrm{Ag} / \mathrm{AgO}$ nanoparticles in the coating structure, which exhibits strong antibacterial properties. All the tested membranes with $\mathrm{TiO}_{2}+\mathrm{AgO}$ coatings indicated very good photocatalytic properties 
when irradiated with UV. The doping of $\mathrm{TiO}_{2}$ coating with $\mathrm{AgO}$ led to an increase in photocatalytic properties in visible light compared to the one-component coating on the polymeric membranes. At the same time, the authors reported no negative influence of the coating on the filtration properties of the membrane. In the case of the membrane with the $\mathrm{TiO}_{2}+\mathrm{AgO}$ coating deposited on the membrane at the magnetron powers, $\mathrm{P}_{\mathrm{M}-\mathrm{Ti}}=1000 \mathrm{~W}$ the permeate flux was similar to the no-coated membrane. The achieved results are very promising for polymeric material science, giving a prospect for potential application of thin film $\mathrm{TiO}_{2}+\mathrm{AgO}$ coatings onto the surface of polyamide membranes.

Author Contributions: Conception J.K.-G.; Coatings deposition processes J.K.-G. and S.S.; Structure characterization J.K.-G. and P.W.; Bactericidal properties E.W. and W.B.; Photocatalytic and Filtration properties M.Ł. All authors have read and agreed to the published version of the manuscript.

Funding: This work was supported by the National Centre for Research and Development in Poland carried out within the project LIDER VII "Multifunctional polymer membranes modified using hybrid technology of surface engineering", no. LIDER/31/0092/L-7/15/NCBR/2016.

Institutional Review Board Statement: Not applicable.

Informed Consent Statement: Not applicable.

Data Availability Statement: Not applicable.

Conflicts of Interest: The authors declare no conflict of interest.

\section{References}

1. Kołtuniewicz, A.B.; Drioli, E. Membranes in Clean Technologies. Theory and Practice, Vol. 1-2; WILEY-VCH Verlag GmbH \& Co: Weinheim, Germany, 2008.

2. Ursino, C.; Castro-Muñoz, R.; Drioli, E.; Gzara, L.; Albeirutty, M.H.; Figoli, A. Progress of Nanocomposite Membranes for Water Treatment. Membranes 2018, 8, 18. [CrossRef] [PubMed]

3. Nguyen, T.; Roddick, F.A.; Fan, L. Biofouling of Water Treatment Membranes: A Review of the Underlying Causes, Monitoring Techniques and Control Measures. Membranes 2012, 2, 804-840. [CrossRef] [PubMed]

4. Subramani, A.; Hoek, E.M.V. Direct observation of initial microbial deposition onto reverse osmosis and nanofiltration membranes. J. Membr. Sci. 2008, 319, 111-125. [CrossRef]

5. Boussu, K.; Belpaire, A.; Volodin, A.; van Haesendonck, C.; van der Meeren, P.; Vandecasteele, C.; van der Bruggen, B. Influence of membrane and colloid characteristics on fouling of nanofiltration membranes. J. Membr. Sci. 2007, 289, 220-230. [CrossRef]

6. Najjar, A.; Sabri, S.; Al-Gaashani, R.; Atieh, M.A.; Kochkodan, V. Antibiofouling Performance by Polyethersulfone Membranes Cast with Oxidized Multiwalled Carbon Nanotubes and Arabic Gum. Membranes 2019, 9, 32. [CrossRef] [PubMed]

7. Tilahun, A.; Haddis, S.; Hadush, A.T.T. Review on Biofilm and Microbial Adhesion. Int. J. Microbiol. Res. 2016, 3, 63-73. [CrossRef]

8. Garrett, T.R.; Bhakoo, M.; Zhang, Z. Bacterial adhesion and biofilms on surfaces. Progr. Nat. Sci. 2008, 18, 1049-1056. [CrossRef]

9. Vanysacker, L.; Denis, C.; Declerck, P.; Piasecka, A.; Vankelecom, I.F.J. Microbial Adhesion and Biofilm Formation on Microfiltration Membranes: A Detailed Characterization Using Model Organisms with Increasing Complexity. BioMed Res. Int. 2013, 2013, 470867. [CrossRef]

10. Kacprzyńska-Gołacka, J.; Kowalik-Klimczak, A.; Skowroński, J.; Rajewska, P.; Wieciński, P.; Smolik, J. Możliwości wykorzystania plazmowych technik inżynierii powierzchni do modyfikacji membran polimerowych. Polimery 2018, 5, $353-361$.

11. Kacprzyńska-Gołacka, J.; Kowalik-Klimczak, A.; Woskowicz, E.; Wieciński, P.; Łożyńska, M.; Sowa, S.; Barszcz, W.; Kaźmierczak, B. Microfiltration Membranes Modified with Silver Oxide by Plasma Treatment. Membranes 2020, 10, 133. [CrossRef]

12. Yadav, H.M.; Kim, J.; Pawar, S.H. Developments in photocatalytic antibacterial activity of nano TiO 2 : A review. Korean J. Chem. Eng. 2016, 33, 1989-1998. [CrossRef]

13. Vatanpoura, V.; Madaenia, S.S.; Khataeeb, A.R.; Salehia, E.; Zinadinia, S.; Monfareda, H.A. TiO 2 embedded mixed matrix PES nanocomposite membranes: Influence of different sizes and types of nanoparticles on antifouling and performance. Desalination 2012, 292, 19-29. [CrossRef]

14. Wafi, A.; Szabó-Bárdos, E.; Horváth, O.; Pósfai, M.; Makó, É.; Juzsakova, T.; Fónagy, O. The Photocatalytic and Antibacterial Performance of Nitrogen-Doped TiO2: Surface-Structure Dependence and Silver-Deposition Effect. Nanomaterials 2020, 10, 2261. [CrossRef] [PubMed]

15. Kacprzyńska-Gołacka, J.; Osuch-Słomka, E.; Wieciński, P.; Garbacz, H.; Skowroński, J.; Kowalik-Klimczak, A.; Smolik, J.; Mazurkiewicz, A. The impact of working gas atmosphere on phase composition and microstructure of $\mathrm{TiO}_{2}$ coating prepared by reactive magnetron sputtering. In Proceedings of the 26th International Conference on Metallurgy and Materials, Brno, Czech Republic, 24-26 May 2017. 
16. Kacprzyńska-Gołacka, J.; Sowa, S.; Kowalik-Klimczak, A.; Rajewska, P.; Stanisławek, E.; Wieciński, P. The Conception and Design of Polymeric Membranes Modification Technology Using Surface Engineering Techniques. In Proceedings of the 9th International Conference Nanomaterials: Applications \& Properties (NAP), Odesa, Ukraine, 15-20 September 2019; pp. 01TFC31-1-01TFC31-3. [CrossRef]

17. Alotaibi, A.M.; Williamson, B.A.D.; Sathasivam, S.; Kafizas, A.; Alqahtani, M.; Sotelo-Vazquez, C.; Buckeridge, J.; Wu, J.; Nair, S.P.; Scanlon, D.O.; et al. Enhanced Photocatalytic and Antibacterial Ability of Cu-Doped Anatase $\mathrm{TiO}_{2}$ Thin Films: Theory and Experiment. ACS Appl. Mater. Interfaces 2020, 12, 15348-15361. [CrossRef]

18. He, X.; Zhang, G.; Wang, X.; Hang, R.; Huang, X.; Qin, L.; Tang, B.; Zhang, X. Biocompatibility, corrosion resistance and antibacterial activity of $\mathrm{TiO}_{2} / \mathrm{CuO}$ coating on titanium. Ceram. Int. 2017, 43, 16185-16195. [CrossRef]

19. Sethi, D.; Sakthivel, R. $\mathrm{ZnO} / \mathrm{TiO}_{2}$ composites for photocatalytic inactivation of Escherichia coli. J. Photochem. Photobiol. B Biol. 2017, 168, 17-123. [CrossRef]

20. Wysocka, I.; Kowalska, E.; Trzciński, K.; Łapiński, M.; Nowaczyk, G.; Zielińska-Jurek, A. UV-Vis-induced degradation of phenol over magnetic photocatalysts modified with Pt, Pd, $\mathrm{Cu}$ and Au nanoparticles. Nanomaterials 2018, 8, 28. [CrossRef]

21. Harikishore, M.; Sandhyarani, M.; Venkateswarlu, K.; Nellaippan, T.A.; Rameshbabu, N. Effect of Ag Doping on Antibacterial and Photocatalytic Activity of Nanocrystalline $\mathrm{TiO}_{2}$. Procedia Mater. Sci. 2014, 6, 557-566. [CrossRef]

22. Al Suliman, N.; Awada, C.; Alshoaibi, A.; Shaalan, N.M. Simple Preparation of Ceramic-Like Materials Based on 1D-Agx(x=0, 5, 10, 20, $40 \mathrm{mM}) / \mathrm{TiO}_{2}$ Nanostructures and Their Photocatalysis Performance. Crystals 2020, 10, 1024. [CrossRef]

23. Komaraiah, D.; Radha, E.; Sivakumar, J.; Ramana Reddy, M.V.; Sayanna, R. Photoluminescence and photocatalytic activity of spin coated Ag+ doped anatase $\mathrm{TiO}_{2}$ thin films. Opt. Mater. 2020, 108, 110401. [CrossRef]

24. Spilarewicz-Stanek, K.; Jakimińska, A.; Kisielewska, A.; Batory, D.; Piwoński, I. Understanding the Role of Silver Nanostructures and Graphene Oxide Applied as Surface Modification of $\mathrm{TiO}_{2}$ in Photocatalytic Transformations of Rhodamine B under UV and Vis Irradiation. Materials 2020, 13, 4653. [CrossRef] [PubMed]

25. Thukkaram, M.; Cools, P.; Nikiforov, A.; Rigole, P.; Coenye, T.; Van Der Voort, P.; Du Laing, G.; Vercruysse, C.; Declercq, H.; Morent, R.; et al. Antibacterial activity of a porous silver doped $\mathrm{TiO}_{2}$ coating on titanium substrates synthesized by plasma electrolytic oxidation. Appl. Surf. Sci. 2020, 500, 144-235. [CrossRef]

26. Navabpour, P.; Ostovarpour, S.; Hampshire, J.; Kelly, P.; Verran, J.; Cooke, K. The effect of process parameters on the structure, photocatalytic and self-cleaning properties of $\mathrm{TiO}_{2}$ and $\mathrm{Ag}-\mathrm{TiO}_{2}$ coatings deposited using reactive magnetron sputtering. Thin Solid Film 2014, 571, 75-83. [CrossRef]

27. Le Ouay, B.; Stellaci, F. Antibacterial activity of silver nanoparticles: A surface science insight. Nano Today 2015, 10, 339-354. [CrossRef]

28. Sri Devi, P.; Vijayalakshmi, K.A. Analysis of antibacterial activity and cytotoxicity of silver oxide doped hydroxyapatite exposed to DC glow discharge plasma. Mater. Today Proc. 2020, 24, 3604-3608. [CrossRef]

29. Duffy, L.L.; Osmond-McLeod, M.J.; Judy, J.; King, T. Investigation into the antibacterial activity of silver, zinc oxide and copper oxide nanoparticles against poultry-relevant isolates of Salmonella and Campylobacter. Food Control 2018, 92, 293-300. [CrossRef]

30. Slavin, S.N.; Asnis, J.; Häfeli, U.O.; Bach, H. Metal nanoparticles: Understanding the mechanisms behind antibacterial activity. J. Nanobiotechnol. 2017, 15. [CrossRef]

31. Li, Y.; Zhang, W.; Niu, J.; Chen, Y. Mechanism of Photogenerated Reactive Oxygen Species and Correlation with the Antibacterial Properties of Engineered Metal-Oxide Nanoparticles. ACS Nano 2012, 6, 5164-5173. [CrossRef]

32. Albiter, E.; Valenzuela, M.A.; Alfaro, S.; Valverde-Aguilar, G.; Martinez-Pallares, F.M. Photocatalytic deposition of Ag nanoparticles on $\mathrm{TiO}_{2}$ : Metal precursor effect on the structural and photoactivity properties. J. Saudi Chem. Soc. $2015,19,563-573$. [CrossRef]

33. Mogal, S.I.; Gandhi, V.G.; Mishra, M.; Tripathi, S.; Shripathi, T.; Joshi, P.A.; Shah, D.O. Single-Step Synthesis of Silver-Doped Titanium Dioxide: Influence of Silver on Structural, Textural, and Photocatalytic Properties. Ind. Eng. Chem. Res. 2014, 53, 5749-5758. [CrossRef]

34. Din, M.I.; Khalid, R.; Hussain, Z. Minireview: Silver-Doped Titanium Dioxide and Silver-Doped Zinc Oxide Photocatalysts. Anal. Lett. 2018, 51, 892-907. [CrossRef]

35. Glez, V.R.; Hernandez-Gordillo, L. Silver-Based Photocatalysts: A Special Class. In American Jewish Year Book; Springer: Cham, Switzerland, 2018; Chapter 8, pp. 221-239.

36. Kodom, T.; Rusen, E.; Calinescu, I.; Mocanu, A.; Somoghi, R.; Dinescu, A.; Diacon, A.; Boscornea, C. Silver Nanoparticles Influence on Photocatalytic Activity of Hybrid Materials Based on $\mathrm{TiO}_{2} \mathrm{P}_{25}$. J. Nanomater. 2015, 2015, 210734. [CrossRef]

37. Seery, M.K.; George, R.; Floris, P.; Pillai, S.C. Silver doped titanium dioxide nanomaterials for enhanced visible light photocatalysis. J. Photochem. Photobiol. A Chem. 2007, 189, 258-263. [CrossRef]

38. Xu, J.; Xiao, X.; Ren, F.; Wu, W.; Dai, Z.; Cai, G.; Zhang, S.; Zhou, J.; Mei, F.; Jaing, C. Enhanced photocatalysis by coupling of anatase $\mathrm{TiO}_{2}$ film to triangular Ag nanoparticle island. Nanoscale Res. Lett. 2012, 7, 239-245. [CrossRef] 